\title{
Review
}

\section{Environmental implications of gene flow from sugar beet to wild beet - current status and future research needs}

\author{
Detlef BARTSCH ${ }^{1, *}$, Joel CUGUEN ${ }^{2}$, Enrico BIANCARDI ${ }^{3}$, and Jeremy SWEET ${ }^{4}$ \\ ${ }^{1}$ Robert Koch Institute - Center for Gene Technology, Nordufer 20, 13533 Berlin, Germany \\ ${ }^{2}$ Laboratoire de Génétique et Évolution des Populations Végétales, UMR CNRS 8016 - FR CNRS 1818, \\ Université de LILLE 1, 59655 Villeneuve d'Ascq, France \\ ${ }^{3}$ Istituto Sperimentale per le Colture Industriali, Viale Amendola 82, 45100 Rovigo, Italy \\ ${ }^{4}$ NIAB, Huntingdon Road, Cambridge CB3 OLE, United Kingdom
}

Gene flow via seed or pollen is a basic biological process in plant evolution. The ecological and genetic consequences of gene flow depend on the amount and direction of gene flow as well as on the fitness of hybrids. The assessment of potential risks of transgenic plants should take into account the fact that conventional crops can often cross with wild plants. The precautionary approach in risk management of genetically modified plants (GMPs) may make it necessary to monitor significant wild and weed populations that might be affected by transgene escape. Gene flow is hard to control in wind-pollinated plants like beet (Beta vulgaris). In addition, wild beet populations potentially can undergo evolutionary changes which might expand their geographical distribution. Unintended products of cultivated beets pollinated by wild beets are weed beets that bolt and flower during their first year of planting. Weed beets cause yield losses and can delay harvest. Wild beets are important plant genetic resources and the preservation of wild beet diversity in Europe has been considered in biosafety research. We present here the methodology and research approaches that can be used for monitoring the geographical distribution and diversity of Beta populations. It has recently been shown that a century of gene flow from Beta vulgaris ssp. vulgaris has not altered the genetic diversity of wild Beta vulgaris L. ssp. maritima (L.) Arcang. in the Italian sugar beet seed production area. Future research should focus on the potential evolution of transgenic wild beet populations in comparison to these baseline data. Two monitoring models are presented describing how endpoints can be measured: (1) "Pre-post" crop commercialization against today's baseline and (2) "Parallel" to crop commercialization against GMP free reference areas/ populations. Model 2 has the advantage of taking ongoing changes in genetic diversity and population dynamics into account. Model 1 is more applicable if gene flow is so strong that most areas/populations contain GMPs. Important traits that may change the ecology of populations are genes that confer tolerance to biotic and abiotic stress. An assessment of environmental effects can realistically only be based on endpoints and consequences of gene introgression, which may include economic values of biodiversity in littoral and other ecosystems containing wild beet. In general, there is still a great need to harmonize worldwide monitoring systems by the development of appropriate methods to evaluate the environmental impact of introgressed transgenes.

Keywords: plant biosafety / gene flow / gene introgression / sugar beet / wild beet / biodiversity / monitoring

Abbreviations: GMPs: Genetically Modified Plants

\section{INTRODUCTION}

Beets of the species Beta vulgaris are comprised of an extraordinarily variable group in which cultivated, wild and weed forms are often difficult to distinguish
(Tab. 1). This is mainly due to the extensive use of sea beet (Beta vulgaris L. ssp. maritima (L.) Arcang.) gene resources in conventional breeding programs

\footnotetext{
* Corresponding author:

Tel.: +49-(0) 1888-754-3003; fax: +49-(0) 1888-754-3030; e-mail: bartschd@ @ki.de
} 


\section{Bartsch et al.}

Table 1. The Beta vulgaris cultivar-wild plant complex from the view of naturalization status and taxonomic classification. Beta macrocarpa is included as inter-specific hybridization partner.

\begin{tabular}{|c|c|c|}
\hline Habitat & Naturalization status & Taxonomic classification \\
\hline \multicolumn{3}{|l|}{ Outside agricultural area } \\
\hline Europe and Mediterranean area & Wild & $\begin{array}{l}\text { B. vulgaris ssp. maritima } \\
\text { B. macrocarpa } \\
\text { Other Beta } \text { species }\end{array}$ \\
\hline N. America, Australia & Weed & $\begin{array}{l}\text { B. vulgaris ssp. vulgaris } \\
\text { B. vulgaris ssp. maritima } \\
\text { B. macrocarpa }\end{array}$ \\
\hline \multicolumn{3}{|l|}{ Inside agricultural area } \\
\hline Crop plantation & Cultivated & B. vulgaris ssp. vulgaris \\
\hline Sugar beet field & Weed & $\begin{array}{l}\text { B. vulgaris hybrids between } \\
\text { ssp. maritima } x \text { ssp. vulgaris, } \\
\text { B. macrocarpa }\end{array}$ \\
\hline Outside sugar beet field & Ruderal & $\begin{array}{l}\text { B. vulgaris ssp. maritima } \\
\text { B. macrocarpa }\end{array}$ \\
\hline
\end{tabular}

(Ford-Lloyd and Williams, 1975; Ford-Lloyd, 1986; Lange et al., 1999). Sea beet is largely a coastal taxon, with a wide distribution from the Cape Verde and Canary Islands in the west, northward along Europe's Atlantic coast to the North and Baltic Seas (Letschert, 1993). It also extends eastward through the Mediterranean region into Asia where it occurs in Asia Minor, in the central and outer Asiatic steppes, and desert areas as far as western India. Sea beet varies from self-compatible annuals to self-incompatible iteroparous perennials with a life span between one and more than eleven years (Hautekeete et al., 2002). Cultivated B. vulgaris, including Swiss chard, red garden beet and sugar beet, are biennial. The latter is partially self-incompatible due to the extensive use of male sterility genes in sugar beet breeding. The oldest cultivation form - Swiss chard and red garden beet - have been grown for more than 2000 years, and the youngest form - sugar beet - has now been cultivated for 200 years (Lange et al., 1999). The cultivars have not shown unwanted ecological effects despite the introduction and spread of this European species to the New World (Bartsch and Ellstrand, 1999).

Gene flow is by definition the active or passive dispersal of genes via seed, pollen or clonal parts of a plant into the environment (Fig. 1). Since risk is a product of both exposure and hazard, it is clear that biosafety research on environmental effects of genetically modified plants (GMP) should not only target the probability of gene flow, but must also focus on the consequences (and potential hazards) of transgene flow to relatives of transgenic crops (Bartsch and Schuphan, 2002). Today, transgenic sugar beet with recombinant

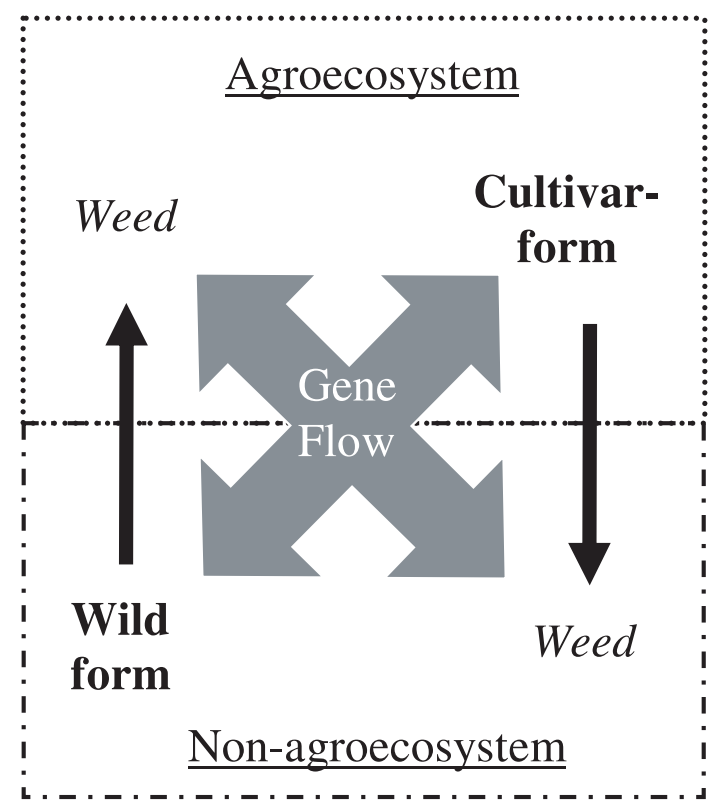

Figure 1. Intra-specific gene flow in a wild-weed-cultivar system: thin black arrows represent the spread of beet plants into unwanted habitats, where they are regarded as weeds. Weeds may also evolve due to gene flow. Wild and cultivar forms of a single species can be protected as genetic resources in one place and eradicated as weed in another. 
herbicide and virus resistance genes is the focus of biosafety research, since, worldwide, regulations ask for risk assessment of this new technology (Bartsch et al., 2001; Crawley et al., 2001; Desplanque et al., 2002). The only realistic way of assessing the environmental effect of transgenic beets is a comparison with the performance and evolutionary history of classically bred cultivars (Bartsch et al., 1996). The aim of this paper is first to summarize our knowledge of past environmental effects of conventional Beta vulgaris gene flow and what additional impact transgenes might have. We start with some general aspects of sugar beet, since this variety is most important in the Beta cultivar-wild plant complex. Second, we highlight geographic hot spots of gene flow in Europe and America, since GMPs will be grown in these areas in the future. Third, we summarize the results of past biosafety research based on an ecologically relevant trait. Since biosafety research cannot be expected to address every possible anticipated and unanticipated risk, we discuss the role of monitoring in risk assessment of GMPs. Finally, we give an outlook on future research needs.

\section{GENERAL ASPECTS OF SUGAR BEET GENE FLOW}

For the wind pollinated sugar beet (Beta vulgaris L. ssp. vulgaris Sugar beet group) gene escape via hybridization is most likely in "off-type" plants that flower during the first year of growth when sugar beet is grown vegetatively or, during the second year of growth after mild winter cold vernalization for commercial seed production. All cultivated forms of beet are more or less biennials. They are sown after spring frosts and their roots and leaves are harvested at the end of their first vegetative season. If young beet plants are grown at low temperatures $\left(0{ }^{\circ} \mathrm{C}\right.$ to $\left.+10{ }^{\circ} \mathrm{C}\right)$ for several days, this results in vernalization of the biennial cultivars (Van Dijk et al., 1997). This physiological response has been widely used for commercial seed production. Beets for seed production are sown at the end of the summer, germinate in autumn, become vernalized during winter and set seeds in temperate climate regions of southwestern France and northeastern Italy at the end of spring (Desplanque et al., 2002). The vernalization requirements for wild and cultivated forms differ among populations. Boudry et al. (2002) found evidence for an adaptive significance of this trait according to geographical climate conditions. In contrast to cultivated forms, the life span in wild Beta vulgaris is genetically fixed according to their demographic distribution range, with up to 11 years maximum in north Brittany (Hautekeete et al., 2002). Even the shortest period observed comprises a one year 2-season span, as found in southwestern France.

Wild B. vulgaris ssp. maritima beets often show an annual habit, since they start flowering in their first year of growth, and usually die after seed set due to unfavourable environmental conditions during hot and dry summers in southern Europe. Flowering in the first season without vernalization is mediated by genetic adaptation to different environmental factors. First year flowering is genetically related to a single locus called B ( $\mathrm{B}=$ bolting), and the inheritance of this trait is only partly Mendelian (Boudry et al., 2002). In sugar beet, genes for cold sensitivity have been selected against so that the plants exhibit low levels of bolting. This is based mainly - but not exclusively - on homozygosity of "bb" in diploid or "bbb" in triploid sugar beet varieties. In summary, the B allele removes vernalization requirement, but it is not unambiguously dominant.

Concerning biosafety related issues of flowering and gene flow, there are three main cropping systems that can enhance gene escape from GM sugar beet:

1. Hybridization of bolting sugar beet with flowering forms of sea beet in seed production areas (Boudry et al., 1993; Mücher et al., 2000).

2. Hibernation and vernalization of old vegetative beet parts remaining on the field after harvest (Pohl-Orf et al., 2000).

3. Vernalization of young seedlings due to unexpected low temperatures below $10{ }^{\circ} \mathrm{C}$ during the early spring growing season (Van Dijk et al., 1997; Pohl-Orf et al., 2000).

\section{HOT SPOTS OF SUGAR BEET GENE FLOW}

Gene flow and introgression from cultivated to wild plants may have important consequences for the conservation of wild plant populations (Ellstrand et al., 1999). Cultivated beets (B. vulgaris ssp. vulgaris) are of particular concern because they are cross-compatible with wild taxa like B. vulgaris ssp. maritima (Darmency, 1994) and B. macrocarpa (Bartsch and Ellstrand, 1999). Geographical "hot spots" for hybridization are located in the seed production areas of eastern England, southwestern France and northeastern Italy (Ford-Lloyd and Hawkes, 1986; Boudry et al., 1993; Bartsch et al., 1999; Stevanato, 1999). For this reason, biodiversity surveys of local wild beet populations and their habitat characteristics are necessary for the assessment of any effect related to the establishment of transgenic beets 
and their offspring (Bartsch and Schuphan, 2002). In addition, the unintended products of hybridization between wild and cultivated beets are weed beets that also bolt and flower during their first year of planting. Weed beets are found in sugar beet fields all over Europe and California, often causing serious yield losses (FordLloyd and Hawkes, 1986; Mücher et al., 2000; Soukup et al., 2002).

Another interesting example of crop-to-wild gene flow occurs in California, where local wild beets belong to two different taxa and have at least three different origins. Bartsch and Ellstrand (1999) found wild beet evolved from escaped Swiss chard or red beet cultivar varieties, and B. macrocarpa, presumably introduced from Spain. In addition, both B. vulgaris ssp. vulgaris and $B$. macrocarpa hybridized locally. Although wild sea beet (B. vulgaris ssp. maritima) probably played some role in the origin of California wild beets, genetic information is insufficient to determine the extent to which hybridization of cultivated beet with sea beet and/or direct introduction of sea beet from Europe contributed to contemporary B. vulgaris-type wild beets in California. A special hot spot for gene flow is the Imperial Valley in Southern California. Here, B. macrocarpa plants grow as weeds in sugar beet fields. Sugar beet is grown in winter culture, and vernalization of the biennial plants is a common phenomenon ("bolting") due to moderate cold winter temperature. A 1998 examination based on 15 sugar beet fields (representing an area of approximately 200 ha) showed a sugar beet bolting rate of 0.6 plants. $\mathrm{m}^{-2}$. An extraordinary cool winter $1997 / 98$ contributed to this phenomenon with periods below freezing $\left(0{ }^{\circ} \mathrm{C}\right)$ in some parts of the area. The density of the annual weed B. macrocarpa was in the range of 2.7 plants. $\mathrm{m}^{-2}$ (representing an area of approximately 100 ha of sugar beet plantation examined). Although the annual B. macrocarpa usually flowers earlier than sugar beet bolters, a flowering time overlap was detected in May 1998. Based on 9 species-specific isozymes, introgression of crop alleles in this area was detected at a rate of $2 \%$ in wild beet populations (13 of 594 examined plants), which were morphologically similar to B. macrocarpa, but had isozyme alleles specific to B. vulgaris (Fig. 2). This past gene flow has led to a $d e$ facto increase of genetic diversity in the B. macrocarpa weed (Tab. 2). A question remains: can Californian wild beet be regarded as a plant genetic resource? If wild beet in this area is only regarded as a common weed (according to Fig. 1), genetic diversity monitoring endpoints are not relevant. However, in Europe genetic

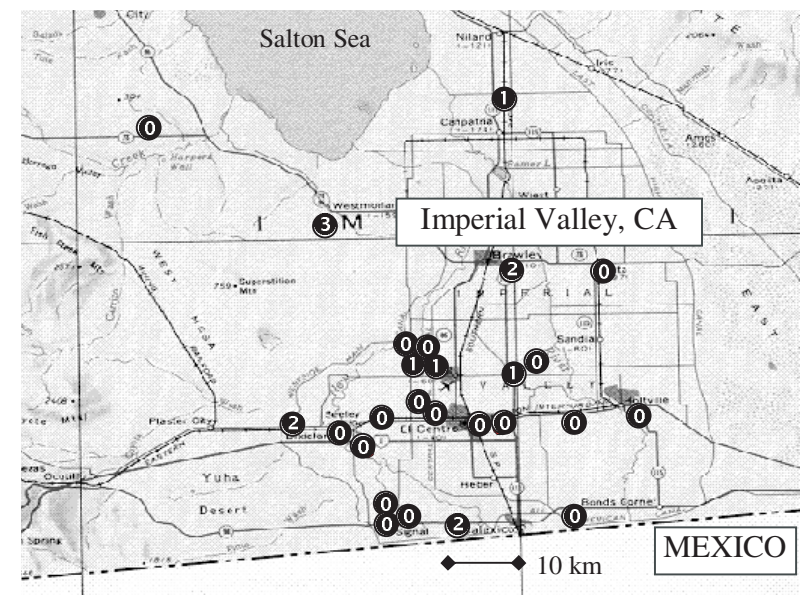

Figure 2. Gene flow from cultivar to weed in California's genus Beta: circles indicate number of individuals of a B. macrocarpa population with gene introgression from B. vulgaris. Total number of populations: 20; sample size was 20 individuals per population (data re-calculated from Bartsch and Ellstrand, 1999).

monitoring in agricultural areas will also have an important role, since the populations of wild beet occur in both agricultural and uncultivated environments.

\section{BIOSAFETY RESEARCH ON TRANSGENIC VIRUS-RESISTANT BEET}

Transgenic sugar beets have been the target of intensive biosafety studies. Beside the insertion of various herbicide resistance genes into the beet genome, the transformation of beet to give resistance to the soil-born virus, beet necrotic yellow vein virus, which causes a serious disease called rhizomania, has been targeted extensively (Bartsch and Schuphan, 2002). In particular, rhizomania-resistant genotypes were examined for sugar beet as well as for sugar beet - Swiss chard hybrids. The beet's ecological performance was compared under various environmental conditions with regard to parameters such as competitiveness, winter hardiness and seed production. No difference was found in seedling performance even under virus infestation (Bartsch et al., 1996). The competitive performance of beet was tested against Chenopodium album, a common weed in sugar beet fields and young fallow. Field experiments carried out between 1993-2001 demonstrated that transgenic sugar beets often grew better than virus-susceptible beets, but only when the virus was present. The difference between susceptible and resistant beets declined as more competing weeds were placed nearby. No differences 
Review: Gene flow from sugar beet

Table 2. Genetic diversity data of Californian wild beet in comparison to other Beta groups.

\begin{tabular}{lccccc}
\hline \hline & $A$ & $A P^{2}$ & $P^{3}$ & $H^{4}$ & $U^{5}$ \\
\hline B. vulgaris USA/Europe $\left(\mathrm{n}_{\text {all }}=47\right)$ & 2.92 & 3.08 & 0.923 & 0.330 & 36 \\
Sugar beet USA/Europe $(\mathrm{n}=16)$ & 2.23 & 2.42 & $\underline{0.923}$ & $\underline{0.343}$ & 29 \\
Swiss chard USA $(\mathrm{n}=4)$ & 1.85 & 2.30 & 0.769 & 0.248 & 24 \\
Red beet USA $(\mathrm{n}=5)$ & 2.15 & 2.60 & 0.769 & 0.250 & 27 \\
Sea beet Europe $(\mathrm{n}=13)$ & $\underline{2.69}$ & $\underline{2.83}$ & $\underline{0.923}$ & 0.304 & $\underline{35}$ \\
Sea beet California $(\mathbf{n}=\mathbf{9})$ & $\mathbf{2 . 3 8}$ & $\mathbf{2 . 6 4}$ & $\mathbf{0 . 8 4 6}$ & $\mathbf{0 . 2 8 4}$ & $\mathbf{3 0}$ \\
\hline B. macrocarpa California $(\mathbf{n}=\mathbf{9})$ & $\mathbf{2 . 3 1}$ & $\mathbf{2 . 8 9}$ & $\mathbf{0 . 6 8 2}$ & $\mathbf{0 . 1 2 5}$ & $\mathbf{2 8}$ \\
B. macrocarpa Europe $(\mathrm{n}=4)$ & 1.62 & 2.13 & 0.615 & 0.145 & 13 \\
\hline
\end{tabular}

${ }^{1}$ Number of populations examined (n); ${ }^{2}$ proportion of polymorphic loci $(A P) ;{ }^{3}$ the mean number of alleles among all loci $(A)$ and among polymorphic loci $(A P) ;{ }^{4}$ estimated heterozygosity $(H)$; and ${ }^{5}$ total number of alleles found within a population group $(U)$. Highest values within $B$. vulgaris are underlined.

were observed in most cases if the virus was absent, but occasionally potential costs of resistance were reported for some transgenic events in sugar beet (Bartsch et al., 2001). Some of the experiments focused on overwintering of transgenic and non-transgenic sugar beet at different locations in Europe representing mild to cold winters in the years 1994-1999. No survival differences were found even under virus infestation conditions. Also, in one experiment, the potential for weed beet production was addressed. It was found that the transgenic genotype had a much "safer" performance because it was less likely to bolt early than the isogenic control (Bartsch et al., 2001). This phenomenon was either caused by somaclonal variation or by a pleiotropic effect of the transformation event. In conclusion, this experiments addressed primarily the ecological consequences of gene flow in a hybrid environment, since crop-variety hybrids were used as a model for crop-wild crosses in the experiments. By complementary use or transgenic and near-isogenic genotypes, direct comparisons were made in experiments, so that any difference measured was caused by the transgenic event. For all cases examined, increased fitness effects were not found based on transgenic rhizomania-resistance genes.

Transgenic attributes can be transferred via gene flow to sexually compatible relatives. One pre-requisite condition is sympatric occurrence of cultivars and their hybridization partners. Transgenic attributes are genetically dominant in heterozygotes, and inherited like conventional genes in wild beet populations (Saeglitz et al., 2000). In the GM rhizomania-resistant beet, no difference was found in the hybridization ability of transgenic plants in comparison to non-transgenic controls. The resulting hybrids between sugar beet and wild or weedy relatives were also the subject of studies of germination, competitiveness, winter hardiness and seed production. No special transgenic effect was observed except a potential cost of resistance that was associated with some transformation events (Pohl-Orf et al., 2000). Generally, transgenic sugar beet plants behaved in an ecologically similar manner to non-GMP, if the modified trait confers no advantage under particular environmental or experimental conditions. However, the GMP may perform better than non-GMP when challenged by ecological conditions to which the modified trait confers tolerance. In order to address this issue, Bartsch and Brand (1998) demonstrated that rhizomania is absent in saline wild beet habitats, and concluded that this virus disease cannot play an ecological role there. Only GM weed beet growing in virus infested land will benefit from resistance genes, whether they are of transgenic or of classical breeding origin. This will also apply to herbicide-resistant weed beets in crop rotations using the complementary herbicide.

\section{BEYOND BIOSAFETY: THE ROLE OF MONITORING}

Environmental monitoring is used for post-commercialization assessment of the fate or effects of transgenes in the environment (Suter, 1993). Monitoring requires baseline data of the flux and evolution of a given (eco-) system structure, systems and processes (Fig. 3). Both indirect and direct methods of measurement can be used to detect possible impacts of transgenes or their products. Environmental monitoring of GM agricultural crops and 


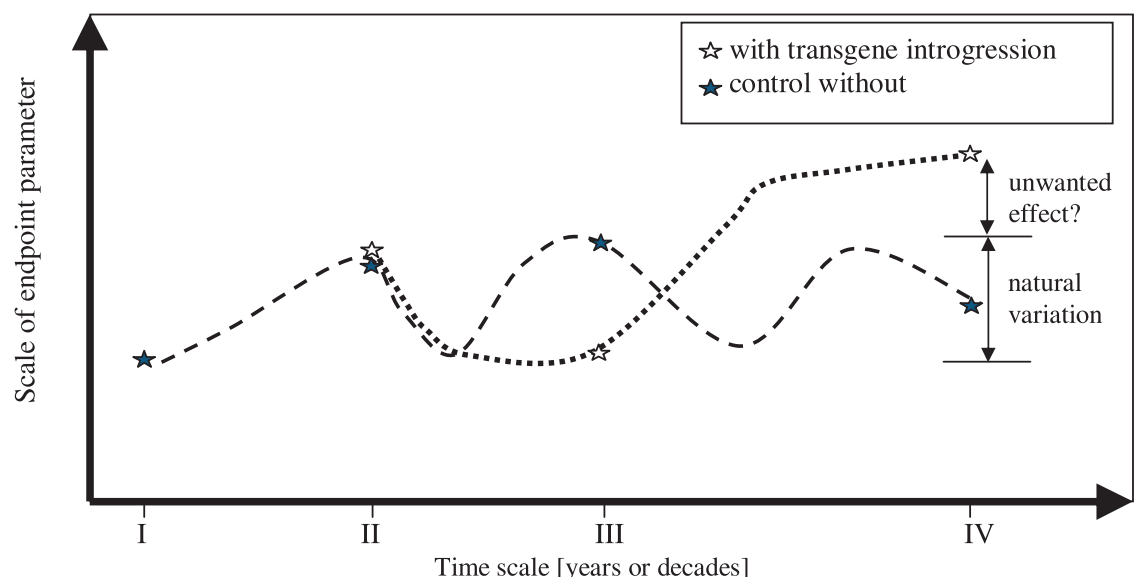

Figure 3. Hypothetical monitoring model: critical points for measuring the potential impact of transgene escape into a wild plant population: I. before transgene release; II. at first commercial transgene release; III. and IV. representative time after transgene release. Suggestions for endpoint parameters are listed in Table 3 . their production practices is generally needed, not because of any specific, identified risk, but to understand the potential contribution or impact of GM crops on sustainable crop production practices.

Monitoring of transgenes is conducted to achieve four specific objectives: (1) confirm compliance with regulatory requirements; (2) collect information necessary for controlling and stewardship of GMPs so as to limit environmental impact; (3) detect and assess parameter changes identified ("known" to be important) by prior environmental impact assessment and (4) detect "unexpected" and potentially damaging effects (Suter, 1993). Monitoring may be recommended to reduce uncertainty remaining from risk assessments, confirm conclusions with additional data, or provide informational feedback on system status or condition (Nickson and Head, 1999). Monitoring is not a substitute for biosafety research or environmental risk assessments, but can be used to validate or verify risk assessments and environmental risk assessments. Monitoring is integrated with research and risk assessment to ensure that ecological systems and processes of value are being protected. A decision to require monitoring is ideally based on the scientific information provided in the risk assessment or some other scientific rationale that a risk is possible. Monitoring resources should be concentrated to areas identified as having a risk potential.

Nickson and Head (1999) have divided monitoring of GMPs into two basic approaches: general or specific. General monitoring, which is also referred to as surveillance in the new EU directive 18-2001, is not necessarily based on any specific hypothesis of risk. It could be accomplished using expertise and infrastructure already present in agricultural systems and within conservation efforts. By gaining familiarity and experience with GMPs through general monitoring, one can conduct "range-finding" and possibly better define the nature of a perceived risk and benefit. Specific monitoring must be based on a scientific hypothesis. It is science-based monitoring where a protocol with specific interpretable endpoints is used. Eventually, information from general monitoring could be refined through the development of specific monitoring protocols designed to determine what, if any, correlations exist between practices, technologies, activities, etc. used in agriculture and the overall condition of the system.

In the case of beet, any monitoring should focus on the bio-geography and genetic diversity of transgenic wild and weed beet populations in comparison to baseline data, and it will depend on the phenotype of the new traits. Several studies have already delivered useful baseline data at a local scale (Laporte et al., 2001; Raybould and Mogg, 1996; Raybould et al., 1997; Raybould et al., 1998; Tufto et al., 1998; Viard et al., 2002). Two monitoring models can be discussed on how endpoints could be measured: (1) "Pre-post" crop commercialization against today's baseline and (2) "Parallel" to crop commercialization against transgene free reference areas/populations. Model 2 has the advantage of taking ongoing changes in genetic diversity and population dynamics into account (Fig. 3). Model 1 is more applicable if gene flow is so strong that most areas/populations contain genetically modified plants, and natural variation has been measured as baseline beforehand (Fig. 3). In every case we need a baseline in order to detect deviations from natural variation of certain endpoint parameters (Tab. 3).

Causal analytic approaches need to compare transgenic gene flow with conventional gene flow effects (Bartsch and Schuphan, 2002; Reboud et al., 1999). 
Review: Gene flow from sugar beet

Table 3. Suggestions for endpoint parameters on a time scale according to Figure 3.

\begin{tabular}{lccccc}
\hline \hline Time/stage & I & II & III & IV & \\
\hline Endpoint Parameter & Pre commercialization & Post commercialization & Remarks and special tasks \\
\hline a. Population size & C & C & $\mathrm{C}^{2}$ & $\mathrm{C}$ & Population monitoring \\
& & & $\mathrm{T}^{1}$ & $\mathrm{~T}$ & \\
b. Geographic range & $\mathrm{C}$ & $\mathrm{C}$ & $\mathrm{C}$ & $\mathrm{C}$ & Estimation of spread \\
& & $\mathrm{T}$ & $\mathrm{T}$ & \\
c. Genetic diversity & $\mathrm{C}$ & $\mathrm{C}$ & $\mathrm{C}$ & $\mathrm{C}$ & Population monitoring \\
& & $\mathrm{T}$ & $\mathrm{T}$ & \\
d. Level of gene flow & $\mathrm{C}$ & $\mathrm{C}$ & $\mathrm{C}$ & $\mathrm{C}$ & Cause-effect analyses \\
& & $\mathrm{T}$ & $\mathrm{T}$ & $\mathrm{T}$ & \\
e. Fitness & & $\mathrm{C}$ & & $\mathrm{C}$ & Mostly experimental \\
\end{tabular}

Shaded cells represent areas where data are available for the genus Beta (see Sect. Biosafety research ... of this paper). Abbreviations: ${ }^{1} \mathrm{~T}=$ population(s) with transgene introgression; and ${ }^{2} \mathrm{C}=$ control population(s) with no transgene introgression.

In addition, the measurable effect of any transgene needs a broader assessment as to whether the effect is unwanted or acceptable both ecologically (Darmency, 1997; Raybould and Gray, 1993) or legally.

Before the post-commercialization monitoring can start, we need in the case of beet a combination of experimental biosafety research, ecological field observation, and population genetic analysis that will be continued at appropriate time intervals (Saeglitz and Bartsch, 2002). Wild sea beet habitats are found in naturally and man-made disturbed areas (Doney et al., 1990; Driessen et al., 2001; Letschert, 1993). Many populations have rarely more than 100 individuals, as well as very high dynamics in population size (Tab. 4). Year-to-year monitoring data demonstrate the difficulty on how to find significant effects within a great natural variability of population dynamics, but population genetic data can be used to study the evolutionary history of wild populations. As an example, Bartsch et al. (1999) studied population genetics of populations that were exposed to gene flow from traditionally bred cultivated beets into the wild sea beet populations of northeastern Italy. They demonstrated that gene flow from a crop to a wild relative does not necessarily result in a decrease in the genetic diversity of the wild plant, despite the fact that cultivated beets are less diverse and outnumbered the wild relatives by the factor 10000 to 1 . These data support the view that gene flow alone should be not regarded as an adverse environmental effect of transgenic plants. In addition, no relationship between genetic diversity (Fig. 4, in terms of heterozygosity) and population size was found. An explanation for this phenomenon can be a high amount of gene flow, the great temporal variation in population size, and the existence of a seed bank. Founder effects or genetic bottlenecks seem to play a minor role in the nature of Beta populations in Italian coastal areas.

In Germany, coastal areas wild B. vulgaris ssp. maritima is actually expanding its geographical distribution. This phenomenon takes place without any influence of transgenic introgression, since transgenic cultivars are still not grown in this region even for small scale field test releases (Driessen et al., 2001). These examples make clear that any observation of GMP spread can only be assessed by help of baseline knowledge of natural population genetics and dynamics. Many annual and biannual species occur as metapopulations (Eriksson, 1996) - making rigorous monitoring difficult to carry out. Important factors influencing high variability of population size and diversity are crop rotation, seed bank dynamics and habitat fragmentation. Monitoring should therefore focus on genetic diversity parameters like isozyme allele frequency or other molecular techniques (Bartsch et al., 1999; Driessen et al., 2001).

\section{OUTLOOK: RESEARCH PRIORITIES FOR TRANSGENIC SUGAR BEET}

Gene flow is not a new phenomenon of crop-wild plant interaction in Beta spp., and research into the historical context of plant breeding implications is helpful to answer risk assessment questions. Future research may 
Table 4. Population size of representative sea beet (B. vulgaris ssp. maritima) populations in northeastern Italy. This area is of special concern since gene flow from sugar beet seed production affects wild beet populations (Bartsch and Schmidt, 1997).

\begin{tabular}{|c|c|c|c|c|c|c|c|c|c|c|}
\hline & Location & 1994 & 1995 & 1996 & 1997 & 1998 & 1999 & 2000 & 2001 & Sum/years \\
\hline 1 & Cervia Saline & 0 & $?$ & $?$ & 200 & 400 & 30 & 8 & 6 & 644 \\
\hline 2 & Boccasette & 70 & 87 & 51 & 20 & 21 & 5 & 14 & 100 & 368 \\
\hline 3 & Scanarello & 5 & 4 & 0 & 6 & 3 & 4 & 6 & 25 & 53 \\
\hline 4 & Porto Levante (sea dike) & 5 & 70 & 1 & 1 & 0 & 0 & 30 & 35 & 142 \\
\hline 5 & Porto Levante (harbor) & 3 & 3 & 6 & 13 & 32 & 23 & 25 & 21 & 126 \\
\hline 6 & Albarella (harbor) & 2 & 27 & 6 & 6 & 1 & 6 & 8 & 2 & 58 \\
\hline 7 & Albarella (near P. Levante) & 18 & $?$ & 2 & 2 & 12 & $?$ & 4 & 12 & 50 \\
\hline 8 & Albarella (yachting club) & 5 & 5 & 29 & 49 & 53 & $?$ & 150 & 100 & 391 \\
\hline 9 & Albarella (inland dike) & 100 & 100 & 28 & 61 & 83 & 5 & 55 & 107 & 541 \\
\hline 10 & Chioggia & 100 & 30 & 100 & 17 & 200 & $?$ & $?$ & 46 & 495 \\
\hline 11 & Pellestrina & 23 & 30 & 12 & 12 & 0 & $?$ & 0 & 88 & 165 \\
\hline 12 & Porto di Malamocco & 70 & $?$ & 8 & 18 & 20 & $?$ & 20 & 54 & 190 \\
\hline 13 & Fusina & 60 & 89 & 10 & 124 & 203 & $?$ & $?$ & 123 & 609 \\
\hline 14 & Cimitero San Michele & 5 & $?$ & 601 & 46 & 200 & $?$ & 90 & 170 & 1112 \\
\hline 15 & San Erasmo (sea dike) & $?$ & $?$ & 20 & 38 & 12 & $?$ & $?$ & 200 & 270 \\
\hline 16 & San Erasmo (inland field) & $?$ & $?$ & $?$ & 3000 & 400 & $?$ & $?$ & 3000 & 6400 \\
\hline 17 & Torcello & $?$ & $?$ & 71 & 600 & 1450 & $?$ & 101 & 3000 & 5222 \\
\hline 18 & Punta Sabbioni & 10 & 1 & 1 & 0 & 0 & 0 & $?$ & 0 & 12 \\
\hline 19 & Bilione (Valpelina) & $?$ & $?$ & 1200 & 500 & 60 & $?$ & $?$ & 27 & 1789 \\
\hline 20 & Ausa Corno & 18 & 4 & 20 & 12 & 0 & 2 & $?$ & 66 & 122 \\
\hline \multirow[t]{2}{*}{21} & Grado (sea dike) & 50 & 200 & 100 & 51 & 65 & $?$ & 5 & 49 & 522 \\
\hline & Approx. sum over locations & 546 & 652 & 2269 & 4778 & 3215 & ? & $?$ & 7232 & \\
\hline
\end{tabular}

Individual numbers $>90$ are in most cases estimations, missing data are marked as "?".

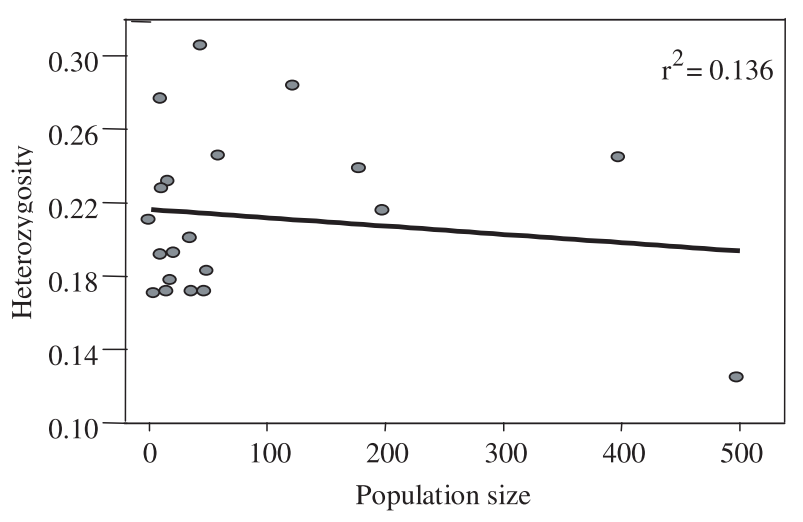

Figure 4. Relationship between heterozygosity calculated from isozyme data and population size of sea beet in NE Italy (data re-calculated from Bartsch et al., 1999). include (a) identification of molecular markers for geographically distinct populations of wild and cultivated beet to identify distinct metapopulations and monitor the impact of gene flow on genetic diversity (Desplanque et al., 1999; Desplanque et al., 2000); (b) gene flow between weed and wild beet in coastal and agricultural areas (Bartsch et al., 1999; Darmency, 1994); (c) experimental measurement of ecological effects of different pests and pathogens on weed and wild beet (Bartsch and Brand, 1998; Ober and Luterbacher, 2002); (d) evaluation of weed beet control methods (Champion, 2000; Desplanque et al., 2002); and (e) more thorough identification and assessment of historical implications of beet breeding on unwanted ecological effects like loss of genetic diversity (Bartsch et al., 1999). However, in order to detect any effect, the establishment and spread of 
specific transformation events in Beta has to be monitored.

There is a need to define what impacts of gene flow are unacceptable in terms of (a) nature conservation efforts; (b) protection of economic value; and (c) responsibility of stakeholders in cases where environmental or economic harm has occurred (Braun, 2002). In relation to (a), it is important that Beta plant genetic resources (gene pool) are protected from loss of diversity (Frese et al., 2001). In order to protect beet crops with relation to (b), the development and recombination of certain transgenic traits that may enhance fitness in natural wild beet habitats or develop aggressive weed beet genotypes by enhancing invasiveness should be avoided. Herbicideand rhizomania-resistance genes seem to play a minor ecological role. So far weed beet is not a problem in crops other than sugar beet, but it might theoretically become more competitive if substantial fitness enhancing traits like stress tolerance are inserted. For (c), the outcome of EU legislation and discussion of threshold levels for transgene frequencies in seed and food products will affect the future biosafety research and monitoring tasks. At this moment there are severe constraints on field scale biosafety studies with novel constructs, due to concerns about gene flow to non-GM crops and the demands from some quarters for zero tolerance of unapproved GM events.

We need to study impacts on genetic diversity and genetic resources in wild Beta and impacts on niches currently occupied by Beta spp. There is also a need for harmonizing methods of utilizing molecular ecology at the different levels of biological organisation. The future task is causal analytic monitoring approach a combination of experimental biosafety research, ecological field observation and population genetic analysis. Where monitoring confirms the possibility of an unanticipated adverse effect, further investigation is needed to establish a correlation, if present, between the use of the GM crop and the observed effect. "Gene flow" alone is from a scientific point of view definitely not a "damage". Instead, it is a significant risk component that has to be monitored but with a causal link to further environmental effects.

An assessment of environmental effects can realistically only be based on endpoints and consequences of gene introgression, which include socio-economic values of biodiversity in littoral and other ecosystems containing wild beet. In general, there is still a great need to harmonise worldwide monitoring systems by the development of appropriate methods to evaluate the environmental impact of introgressed transgenes.

\section{ACKNOWLEDGEMENT}

A group of 17 experts met at an ESF AIGM ${ }^{1}$ sponsored working Group near Venice; Italy 17-20 May 2001 in order to discuss biosafety issues related to transgenic sugar beet (Beta vulgaris ssp. vulgaris). This paper is based on the contributions of the workshop. The authors wish to thank the ESF for funding the workshop and the following participants for their workshop contributions: M. Colombo, A. Cureton, H. Darmency, M. De Biaggi, D. Pascale, G. Grassi, T. Hauser, R.B. Jorgensen, A. Matzk, C. Paoletti, A. Raybould, P. Stevanato, and M. Stevens.

Received July 4, 2001; accepted February 19, 2003.

\section{REFERENCES}

Bartsch D, Brand U (1998) Saline soil condition decreases rhizomania infection of Beta vulgaris. J. Plant Pathol. 80: 219-223

Bartsch D, Ellstrand NC (1999) Genetic evidence for the origin of Californian wild beets (genus Beta). Theor. Appl. Genet. 99: 1120-1130

Bartsch D, Schmidt M (1997) Influence of sugar beet breeding on populations of Beta vulgaris ssp. maritima in Italy. J. Veg. Sci. 8: 81-84

Bartsch D, Schuphan I (2002) Lessons we can learn from ecological biosafety research. J. Biotechnol. 98: 71-77

Bartsch D, Schmidt M, Pohl-Orf M, Haag C, Schuphan I (1996) Competitiveness of transgenic sugar beet resistant to beet necrotic yellow vein virus and potential impact on wild beet populations. Mol. Ecol. 5: 199-205

Bartsch D, Lehnen M, Clegg J, Pohl-Orf M, Schuphan I, Ellstrand NC (1999) Impact of gene flow from cultivated beet on genetic diversity of wild sea beet populations. Mol. Ecol. 8: 1733-1741

Bartsch D, Brand U, Morak C, Pohl-Orf M, Schuphan I, Ellstrand NC (2001) Biosafety of hybrids between transgenic virus-resistant sugar beet and Swiss chard. Ecol. Appl. 11: 142-147

Boudry P, Mörchen M, Saumitou-Laprade P, Vernet P, Van Dijk H (1993) The origin and evolution of weed beets, consequences for the breeding and release of herbicideresistant transgenic sugar-beets. Theor. Appl. Genet. 87: 471-478

Boudry P, McCombie H, Van Dijk H (2002) Vernalization requirement of wild beet Beta vulgaris ssp. maritima: among population variation and its adaptive significance. J. Ecol. 90: 693-793

\footnotetext{
$\overline{1}$ (ESF $=$ European Science Foundation; AIGM $=$ Assessment of the impact of genetically modified plants).
} 
Braun R (2002) People's concerns about biotechnology: some problems and some solutions. J. Biotechnol. 98: 3-8

Champion GT (2000) The biology of weed beet. Brit. Sugar Beet Rev. 68: 53-55.

Crawley MJ, Brown SL, Hails RS, Kohn D, Rees M (2001) Transgenic crops in natural habitats. Nature 408: 682-683

Darmency H (1994) The impact of hybrids between genetically modified crop plants and their related species: introgression and weediness. Mol. Ecol. 3: 37-44

Darmency H (1997) Gene flow between crops and weeds: Risk for new herbicide resistances weeds? In De Prado R, Jorrin J, Garcia-Torres L, eds, Weed and Crop Resistance to Herbicides. Kluver Academic Publishers, Dordrecht, pp 239-248

Desplanque B, Boudry P, Broomberg K, Saumitou-Laprade P, Cuguen J, Van Dijk H (1999) Genetic diversity and gene flow between wild, cultivated and weedy forms of Beta vulgaris L. (Chenopodiaceae), assessed by RFLP and microsatellite markers. Theor. Appl. Genet. 98: 1194-1201

Desplanque B, Viard F, Forcioli D, Bernard J, SaumitouLaprade P, Cuguen J, Van Dijk H (2000) The linkage disequilibrium between cpDNA and mtDNA haplotypes in Beta vulgaris ssp. maritima (L.): the usefulness of both genomes for population genetic studies. Mol. Ecol. 9: 141-154

Desplanque B, Hautekeete N, Van Dijk H (2002) Transgenic weed beets: possible, probable, avoidable? J. Appl. Ecol. 39: 561-571

Doney DL, Whitney ED, Terry J, Frese L, Fitzgerald P (1990) The distribution and dispersal of Beta vulgaris L. ssp. maritima germplasm in England, Wales, and Ireland. J. Sugar Beet Res. 27: 29-37

Driessen S, Pohl M, Bartsch D (2001) RAPD-PCR analysis of the genetic origin of sea beet (Beta vulgaris ssp. maritima) at Germany's Baltic Sea coast. Basic Appl. Ecol. 2: 341-349

Ellstrand NC, Prentice HC, Hancock JF (1999) Gene flow and introgression from domesticated plants into their wild relatives. Annu. Rev. Ecol. Syst. 30: 539-563

Eriksson O (1996) Regional dynamics of plants: a review of evidence for remnant, source-sink and metapopulations. Oikos 77: 248-258

Ford-Lloyd BV (1986) Infraspecific variation in wild and cultivated beets and its effect upon infraspecific classification. In Styles BT, ed, Infraspecific classification of wild and cultivated plants. Clarendon Press, Oxford, pp 331-334

Ford-Lloyd BV, Hawkes JG (1986) Weed beets, their origin and classification. Acta Horticultura 82: 399-401

Ford-Lloyd BV, Williams JT (1975) A revision of Beta section Vulgares (Chenopodiaceae), with new light on the origin of cultivated beets. Bot. J. Linn. Soc. 71: 89-102

Frese L, Desprez B, Ziegler D (2001) Potential of genetic resources and breeding strategies for base-broadening in Beta. In Cooper HD, Spillane C, Hodgkin T, eds, Broadening the genetic base of crop production. IPGRI/FAO, Rome, 2001, pp 295-309
Hautekeete N, Piquot Y, Van Dijk H (2002) Life span in Beta vulgaris maritima: the impacts of disturbance and of age at first reproduction. J. Ecol. 90: 508-516

Lange W, Brandenburg WA, de Bock TSM (1999) Taxonomy and cultonomy of beet (Beta vulgaris L.). Bot. J. Linn. Soc. 130: 81-96

Laporte V, Viard F, Béna G, Valero M, Cuguen J (2001) The spatial structure of sexual and cytonuclear polymorphism in the gynodioecious Beta vulgaris ssp. maritima at a local scale. Genetics 157: 1699-1710

Letschert JPW (1993) Beta section Beta: biogeographical patterns of variation and taxonomy. Wageningen Agricultural University Publications 93: 1-153

Mücher T, Hesse P, Pohl-Orf M, Ellstrand NC, Bartsch D (2000) Characterization of weed beets in Germany and Italy. J. Sugar Beet Res. 37: 19-38

Nickson TE, Head GP (1999) Environmental monitoring of genetically modified crops. J. Environ. Monit. 1: 101-105

Ober E, Luterbacher M (2002) Genotypic variation for drought tolerance in Beta vulgaris. Ann. Bot. 89: 917-924

Pohl-Orf M, Morak C, Wehres U, Saeglitz C, Driessen S, Lehnen M, Hesse P, Mücher T, von Soosten C, Schuphan I, Bartsch D (2000) The environmental impact of gene flow from sugar beet to wild beet - an ecological comparison of transgenic and natural virus tolerance genes. In Fairbairn C, Scoles G, McHughen A, eds, Proceedings of the 6th International Symposium on the Biosafety of Genetically Modified Organisms, July 2000, Saskatoon, Canada, pp 51-55

Raybould AF, Gray AJ (1993) Genetically modified crops and hybridization with wild relatives: a UK perspective. J. Appl. Ecol. 30: 199-219

Raybould AF, Mogg RJ (1996) The genetic structure of Beta vulgaris ssp. maritima (sea beet) populations: RFLPs and isozymes show different patterns of gene flow. Heredity 77: 245-250

Raybould AF, Mogg RJ, Gliddon CJ (1997) The genetic structure of Beta vulgaris ssp. maritima (sea beet) populations. II. Differences in gene flow estimated from RFLP and isozyme loci are habitat-specific. Heredity $\mathbf{7 8}$ : 535-538

Raybould AF, Mogg RJ, Aldam C, Gliddon CJ, Thorpe RS, Clarke RT (1998) The genetic structure of sea beet (Beta vulgaris ssp. maritima) populations. III. Detection of isolation by distance at microsatellite loci. Heredity $\mathbf{8 0}$ : 127-132

Reboud X, Gasquez J, Darmency H (1999) A multisitecooperative research programme on risk assessment of transgenic crops. In Ammann K, Jacot Y, Simonsen V, Kjellsson G, eds, Methods for Risk Assessment of Transgenic Plant III. Ecological risks and prospects of transgenic plants, where do we go from here? A dialogue between biotech industry and science. Birkhäuser Verlag, Basel, pp 17-20 
Saeglitz C, Bartsch D (2002) Gene flow from transgenic plants. AgBiotechNet 4: ABN 084

Saeglitz C, Pohl M, Bartsch D (2000) Monitoring gene escape from transgenic sugar beet using cytoplasmic male sterile bait plants. Mol. Ecol. 9: 2035-2040

Soukup J, Holec J, Vejl P, Skupinova S, Sedlak P (2002) Diversity and distribution of weed beet in the Czech Republic. Journal of Plant Diseases and Protection (z pflanzenkr pflanzenschutz) 18: 67-74

Stevanato P (1999) Ottavio Munerati - 50 anni dopo. Proceedings Accademia dei Concordi: 1-83

Suter GW (1993) Environmental surveillance, In Suter GW, ed, Ecological Risk Assessment. Lewis Publishers, Chelsea, MI, pp 377-383

Tufto J, Raybould AF, Hindar K, Engen S (1998) Analysis of Genetic Structure and Dispersal Patterns in a Population of Sea Beet. Genetics 149: 1975-1985

Van Dijk H, Boudry P, McCombie H, Vernet P (1997) Flowering time in wild beet (Beta vulgaris ssp. maritima) along a latitudinal cline. Acta Oecologia 18: 47-60

Viard F, Bernard J, Desplanque B (2002) Crop-weed interactions in the Beta vulgaris complex at a local scale: allelic diversity and gene flow within sugar beet fields. Theor. Appl. Genet. 104: 688-697 